\title{
IMPLEMENTASI METODE KOOPERATIF TIPE STAD (STUDENT TEAMS ACHIEVEMENT DIVISION) DALAM UPAYA GURU MENINGKATAN AKTIVITAS DAN HASIL BELAJAR SISWA DENGAN MATERI BERIMAN KEPADA KITAB- KITAB ALLAH DI KELAS XI IPA1 SMA NEGERI 1 PONTIANAK
}

\author{
NURJANNAH \\ SMA Negeri 1 Pontianak \\ Email : dranurjannah@gmail.com
}

\begin{abstract}
ABSTRAK
Tujuan penelitian ini adalah sebagai berikut: Untuk mengetahui implementasi metode kooperatif tipe STAD (Student Teams Achievement Division) dalam upaya guru meningkatan aktivitas dan hasil belajar siswa dengan materi beriman kepada kitab-kitab Allah di Kelas XI IPA1 SMA Negeri 1 Pontianak. Berdasarkan observasi diketahui bahwa aktivitas peserta didik yang pasif dalam mengikuti proses pembelajaran dan kurangnya variasi guru dalam menggunakan metode mempengaruhi rendahnya hasil belajar dan aktivitas belajar peserta didik. Hasil penelitian ini menunjukan bahwa aktivitas belajar pada Aktivitas peserta didik selama mengikuti proses pembelajaran dengan menerapkan metode STAD menunjukkan peningkatan yang memuaskan. Hal ini terlihat dari hasil persentase peserta didik pada siklus I (pertama) 75,7\% dan pertemjuan siklus II (kedua) menjadi 84,1\%. Hasil belajar peserta didik kelas XI IPA1 SMA Negeri 1 Pontianak tahun pelajaran 2018/2019 mengalami peningkatan untuk kategori sangat baik dari $38,7 \%$ pada tes akhir pertemuan pertama menjadi $80 \%$ pada tes akhir pada pertemuan kedua dan menjadi $91 \%$.
\end{abstract}

Kata Kunci: Metode Kooperatif Tipe STAD, Aktivitas, Hasil Belajar

\section{PENDAHULUAN}

Guru sebagai ujung tombak pendidikan mengambil peran strategis untuk membantu siswa memiliki sikap dan nilai yang positif. Salah satu sikap positif yang diperlukan seseorang untuk mampu mengembangkan potensinya dengan baik adalah percaya diri. Percaya diri adalah sikap yakin akan kemampuan diri sendiri untuk memenuhi setiap keinginan dan harapannya Sebagai ujung tombak dalam mencapai tujuan pembelajaran di sekolah maka seorang guru bisa mefungsikan dirinya sebagai agen pembelajaran (learning egent) yang berperan sebagai fasilitator, motivator, pemicu dan pemberi inspirasi belajar bagi peserta didik (Darsono, Max dkk (2000: 67).

Guru harus menjadi orang yang memiliki jati diri yang kuat, senantiasa menjadi teladan bagi anak didiknya dan mampu melaksanakan pembelajaran dengan baik, serius dan sepenuh hati, sehingga mampu membangkitkan rasa percaya diri yang kuat dalam diri siswa. Begitupun peserta didik juga harus dapat menghargai kemampuan yang dimilikinya, agar dia memiliki rasa percaya diri yang kuat sehingga mampu mengeluarkan potensi yang dimilkinya dan mampu membuat prestasi belajarnya dengan baik. Kepercayaan diri siswa dan prestasi yang baik dapat dicapai jika didukung dan selalu didorong oleh orangtua di rumah, guru di sekolah dan tentunya lingkungan belajar yang kondusif (Ratumanan, 2002).

Guru menyampaikan materi kepada siswa, kemudian siswa menyimak materi yang diberikan guru sehingga siswa mendapat pengetahuan yang belum diketahuinya. Sebelum melakukan proses belajar mengajar seorang guru harus mempersiapkan segala perangkat yang diperlukan saat proses belajar mengajar berlangsung. Salah satunya adalah sebuah metode Pembelajaran, metode brarti suatu cara atau teknik-teknik tertentu yang dianggap baik (efisien dan efektif) untuk mencapai tujuan pembelajaran.

Pendidikan Agama Islam merupakan ruh dari pembelajaran yang merupakan pengembangan dari tujuan pendidikan nasional secara umum. Ini bukan berarti Pendidikan Agama Islam mengabaikan pendidikan jasmani atau pendidikan praktis lainnya, tetapi 
maksudnya adalah Pendidikan Agama Islam itu menjadi penyeimbang dari kebutuhan peserta didik itu sendiri, karena di samping membutuhkan pendidikan jasmani, akal dan ilmu, mereka juga memerlukan pendidikan mental, budi pekerti, perasaan, kemauan, cita rasa dan kepribadian. Dengan demikian Pendidikan Agama Islam menduduki posisi strategis dalam mempersiapkan sumber daya manusia yang unggul, handal, dan berakhlak (Nizar, 2002)

Dengan demikian tujuan pendidikan Islam adalah pembentukan akhlak dan budi pekerti yang sanggup menghasilkan orang-orang yang bermoral, laki-laki maupun wanita, memiliki jiwa yang bersih, kemauan keras, cita-cita yang benar dan akhlak yang tinggi, mengetahui arti kewajiban dan pelaksanaannya, menghormati hak-hak manusia, mengetahui perbedaan buruk dan baik, menghindari suatu perbuatan yang tercela, dan mengingat Tuhan dalam setiap pekerjaan yang mereka lakukan (Hidayat, 2002: 113)

Islam sebagai agama samawi yang sempurna mengandung berbagai aspek. Secara umum ada aspek aqidah, aspek ibadah dan aspek ahklak. Seorang muslim yang sejati harus dapat mengamalkan ketiga aspek tersebut secara integral. Misalnya seseorang yang beraqidah benar, maka ia akan beribadah sesuai tuntunan dan sekaligus akan teraktualisasi dalam sikap melalui akhlak yang baik. Ibarat sebuah pohon, aqidah adalah akarnya, ibadah adalah batang, cabang dan rantingnya, maka akhlak adalah daun buah dan bunganya. Dapat dikatakan akhlak adalah hasil dari semua amalan seorang Muslim.

Salah satu upaya peningkatan iman dan takwa bagi kaum Muslimin itu ialah menampilkan kepribadian dalam berbusana dan berhias serta bertamu dan menerima tamu yang harus sesuai dengan petunjuk dan tuntunan serta selaras dengan ketentuan hukum dan ajaran agama. Khususnya yang berhubungan dengan pakaian, yang berfungsi untuk menutupi aurat dan memperindah jasmani dan manusia. Dijelaskan bahwa Allah telah menyediakan banyak bahan baku pakaian atau penutup aurat yang dijadikan bagi manusia agar memenuhi unsur etik dalam kehidupannya.

Tujuan pokok beriman kepada kitab-kitab Allah yaitu peserta didik agar sepanjang hidupnya tetap berada dalam fitrah Nya, baik dalam arti suci dan bersih dari dosa dan maksiat, maupun dalam arti bersyahadad atau bertauhid kepada Allah Swt. serta menanamkan prinsipprinsip, kaedah-kaedah, atau norma-norma tentang baik-buruk atau terpuji- tercela ke dalam diri dan kepribadian peserta didik agar mereka berkemampuan memilih untuk menampilkan prilaku yang baik atau terpuji dan menghindari atau meninggalkan semua perilaku buruk atau tercela dalam kehidupannya (Al Rasyidin. 2008: 75)

Sehubungan dengan eksistensi Pendidikan Agama Islam sebagai penyeimbang dari kebutuhan pendidikan peserta didik, pembelajaran Pendidikan Agama Islam pada setiap jenis, jalur dan jenjang pendidikan haruslah memberikan kontribusi dalam pembentukan kepribadian peserta didik, baik dalam aspek kognitif, psikomotor apalagi aspek afektif. Untuk mewujudkan semua itu pembelajaran Pendidikan Agama Islam harus dikemas dengan metode dan strategi pembelajaran yang aktif, kreatif, efektif, menarik, menantang dan menyenangkan.

\section{METODE PENELITIAN}

Dalam pelaksanaan tindakan yang sedemikian, guru dilibatkan dalam proses penelitian kelasnya, terutama pada aspek aksi dan refleksi terhadap permasalahan apa yang harus diteliti dalam kelasnya sendiri, terutama pada aspek aksi dan refleksi terhadap praktik-praktik pembelajaran di kelas. Sejak awal dalam melakukan penelitian diusahakan untuk mencari makna data yang dikumpulkan. Untuk itu perlu mengambil kesimpulan dari data yang diperoleh dari lokasi penelitian. Seperti gambar di bawah ini: 


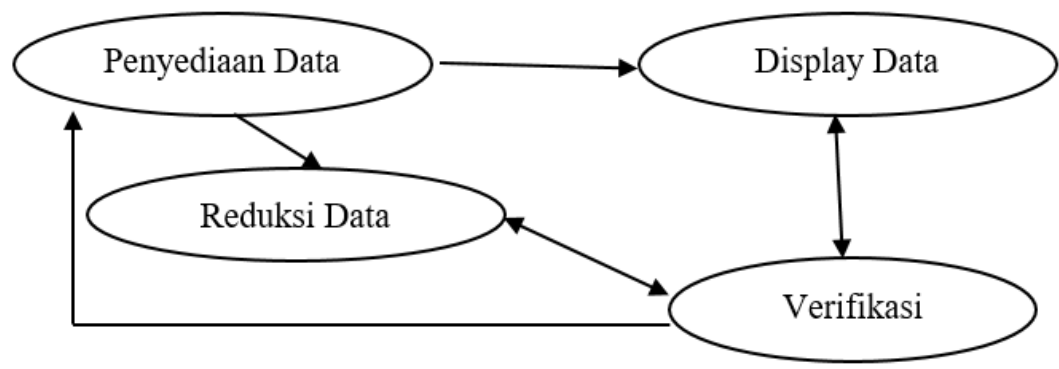

Gambar 1. Diagram Alur Data

Untuk lebih jelas berikut ini dikemukakan model siklus Penelitian Tindakan Kelas (PTK):

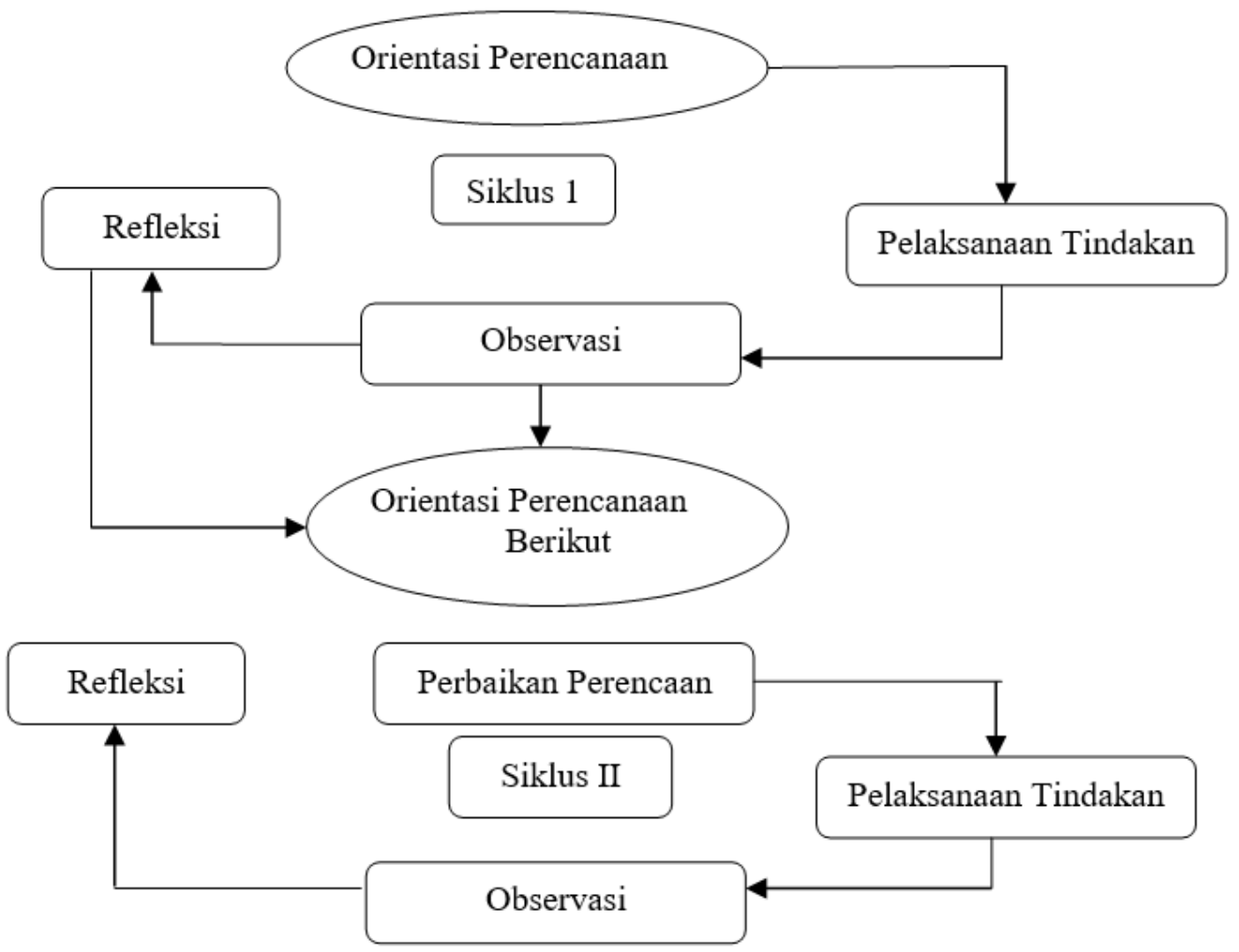

Gambar 1. Siklus Penelitian Tindakan Kelas

\section{HASIL DAN PEMBAHASAN}

\section{Hasil Penelitian Siklus I}

Hasil observasi aktivitas siswa dalam proses pembelajaran dapat dilihat pada tabel sebagai berikut:

Tabel 1. Hasil Observasi Aktivitas Siswa dalam Proses Pembelajaran siklus I

\begin{tabular}{|c|l|c|l|}
\hline No & \multicolumn{1}{|c|}{ Nama Siswa } & Skor & Keterangan \\
\hline 1 & Ade Ristiana Zuliani & 66 & Tidak Tuntas \\
\hline 2 & Aisyah & 73 & Tidak Tuntas \\
\hline 3 & Amalia Zulfa & 74 & Tidak Tuntas \\
\hline 4 & Anisa Fadyawati & 80 & Tuntas \\
\hline 5 & Ardi Kurniawan & 70 & Tidak Tuntas \\
\hline 6 & Aulya Dewi Permadi & 66 & Tidak Tuntas \\
\hline 7 & Bram Darmawan & 60 & Tidak Tuntas \\
\hline 8 & Dea Latifa Wiyana Putri & 60 & Tidak Tuntas \\
\hline 9 & Fadilah Fitri Kemuning & 70 & Tidak Tuntas \\
\hline 10 & Fanya Mahavira Putri & 75 & Tuntas \\
\hline
\end{tabular}




\begin{tabular}{|c|l|c|l|}
\hline 11 & Fazry Ramadhani & 74 & Tidak Tuntas \\
\hline 12 & Guruh Anugrah Putra & 73 & Tidak Tuntas \\
\hline 13 & Hani Khairunnisa & 71 & Tidak Tuntas \\
\hline 14 & Ihsan Luthfi Althoriq & 73 & Tidak Tuntas \\
\hline 15 & Khansa Hana Dzakiyyah & 73 & Tidak Tuntas \\
\hline 16 & Lunggi Januaputri & 81 & Tuntas \\
\hline 17 & $\begin{array}{l}\text { Muhammad Hafizt Putro } \\
\text { Dwino }\end{array}$ & 74 & Tidak Tuntas \\
\hline 18 & $\begin{array}{l}\text { Muhammad Rakha } \\
\text { Nugraha Azka }\end{array}$ & 85 & Tuntas \\
\hline 19 & Nabillah Aura Syahrani & 87 & Tuntas \\
\hline 20 & $\begin{array}{l}\text { Nadia Annisa } \\
\text { Nurhafizah }\end{array}$ & 74 & Tidak Tuntas \\
\hline 21 & Narisa Berliana & 88 & Tuntas \\
\hline 22 & Nasywa Rabitha & 65 & Tidak Tntas \\
\hline 23 & $\begin{array}{l}\text { Nazha Duta Ulkitasalka } \\
\text { Muharraran }\end{array}$ & 65 & Tidak Tuntas \\
\hline 24 & $\begin{array}{l}\text { Puti Zella Fatima Ponti } \\
\text { Sjamsuar }\end{array}$ & 70 & Tidak Tuntas \\
\hline 25 & Qothrunnada Ratu & 91 & Tuntas \\
\hline 26 & Khaumi & 81 & Tuntas \\
\hline 27 & Rifky Fajar Rachmawan & 92 & Tuntas \\
\hline 28 & Sabrina Adelia & 91 & Tuntas \\
\hline 29 & Sekar Harum Fauzanna & 70 & Tidak Tuntas \\
\hline 30 & Sisca Amellia Nazira & 80 & Tuntas \\
\hline & & & \\
\hline
\end{tabular}

Tabel 2. Hasil Belajar Peserta Didik Pada Siklus I (Pertama)

\begin{tabular}{|c|l|l|l|l|}
\hline No & Nilai & Jumlah $(\mathrm{F})$ & Presentase $(\%)$ & Keterangan \\
\hline 1 & $91-100$ & 3 & $10 \%$ & Sangat Kompeten \\
\hline 2 & $81-90$ & 5 & $16,7 \%$ & Kompeten \\
\hline 3 & $75-80$ & 3 & $10 \%$ & Cukup Kompeten \\
\hline 4 & $<75$ & 19 & $63.3 \%$ & Tidak Kompeten \\
\hline & Jumlah & 30 & $100 \%$ & \\
\hline
\end{tabular}

Keterangan:

Jumlah : Jumlah total skor indikator atau aspek yang diamati.

Total persentase dari aktivitas STAD peserta didik adalah:

$\underline{\text { Skor perolehan }} \times 100 \%=\underline{672} \times 100 \%=74,7 \%$

Skor maksimal $\quad 900$

Dengan demikian tingkat aktivitas peserta didik yang ditemukan pada siklus I (pertama) dapat dikatakan belum mencapai indikator keberhasilan dalam penelitian tindakan kelas, karena indikator yang peneliti tetap $80 \%$. Jadi peneliti simpulkan bahwa pada siklus I (pertama) aktivitas peserta didik dalam mendemonstrasikan dan memerankan masih rendah. Angka 74,7\% merupakan angka kumulatif dari indikator sikap, keaktifan, respon, kemampuan, kerjasama dan kebenaran syariat peserta didik dalam mengikuti pembelajaran dengan metode STAD.

Sikap yang dimaksud adalah sikap peserta didik dalam berprilaku dan menghargai teman waktu proses pembelajaran, misalnya mendengar pendapat temannya, tidak membuat keributan, dan berprilaku sopan saat proses pembelajaran. Sikap ini terlihat hingga $74 \%$. 
Selanjutnya terlihat tingkat keaktifan peserta didik dalam mengemukakan pendapat dan menyatakan ide dengan jelas mencapai $74 \%$. Respon peserta didik dalam menanggapi permasalahan yang terjadi dalam proses pembelajaran, respon ini mencapai $76 \%$. Kemampuan peserta didik dalam melaksanakan proses pembelajaran mencapai $73,3 \%$. Kerja sama peserta didik dengan peserta didik lainnya dan sesama kelompok dalam proses pembelajaran, ini terlihat mencapai $75,3 \%$, dan kebenaran syariah yaitu kebenaran peserta didik menurut ajaran Islam dalam proses pembelajaran mencapai 75,3\%.

\section{Hasil Penelitian Siklus II}

Hasil observasi terhadap aktivitas peserta didik pada siklus II (kedua) dapat dilihat pada tabel di bawah ini.

Tabel 3. Hasil Observasi Aktivitas Siswa dalam Proses Pembelajaran siklus II

\begin{tabular}{|c|c|c|c|}
\hline No & Nama Siswa & Skor & Keterangan \\
\hline 1 & Ade Ristiana Zuliani & 72 & Tidak Tuntas \\
\hline 2 & Aisyah & 80 & Tuntas \\
\hline 3 & Amalia Zulfa & 78 & Tuntas \\
\hline 4 & Anisa Fadyawati & 90 & Tuntas \\
\hline 5 & Ardi Kurniawan & 84 & Tuntas \\
\hline 6 & Aulya Dewi Permadi & 71 & Tidak Tuntas \\
\hline 7 & Bram Darmawan & 65 & Tidak Tuntas \\
\hline 8 & Dea Latifa Wiyana Putri & 66 & Tidak Tuntas \\
\hline 9 & Fadilah Fitri Kemuning & 76 & Tuntas \\
\hline 10 & Fanya Mahavira Putri & 76 & Tuntas \\
\hline 11 & Fazry Ramadhani & 80 & Tuntas \\
\hline 12 & Guruh Anugrah Putra & 80 & Tuntas \\
\hline 13 & Hani Khairunnisa & 80 & Tuntas \\
\hline 14 & Ihsan Luthfi Althoriq & 80 & Tuntas \\
\hline 15 & Khansa Hana Dzakiyyah & 80 & Tuntas \\
\hline 16 & Lunggi Januaputri & 90 & Tuntas \\
\hline 17 & Muhammad Hafizt Putro & 80 & Tuntas \\
\hline 18 & Muhammad Rakha Nugraha & 90 & Tuntas \\
\hline 19 & Nabillah Aura Syahrani & 91 & Tuntas \\
\hline 20 & Nadia Annisa Nurhafizah & 93 & Tuntas \\
\hline 21 & Narisa Berliana & 90 & Tuntas \\
\hline 22 & Nasywa Rabitha & 70 & Tidak Tuntas \\
\hline 23 & Nazha Duta Muharraran & 69 & Tidak Tuntas \\
\hline 24 & Puti Zella Ponti Sjamsuar & 79 & Tuntas \\
\hline 25 & Qothrunnada Ratu Khaumi & 94 & Tuntas \\
\hline 26 & Rifdah Hilmi Ibtisamah & 93 & Tuntas \\
\hline 27 & Rifky Fajar Rachmawan & 94 & Tuntas \\
\hline 28 & Sabrina Adelia & 95 & Tuntas \\
\hline 29 & Sekar Harum Fauzanna & 80 & Tuntas \\
\hline 30 & Sisca Amellia Nazira & 90 & Tuntas \\
\hline
\end{tabular}

Tabel 4. Hasil Belajar Peserta Didik Pada Siklus II

\begin{tabular}{|l|l|l|l|l|}
\hline No & Nilai & Jumlah $(\mathrm{F})$ & Presentase $(\%)$ & Keterangan \\
\hline 1 & $91-100$ & 6 & $20 \%$ & Sangat Kompeten \\
\hline 2 & $81-90$ & 6 & $20 \%$ & Kompeten \\
\hline 3 & $75-80$ & 12 & $40 \%$ & Cukup Kompeten \\
\hline 4 & $<75$ & 6 & $20 \%$ & Tidak Kompeten \\
\hline & Jumlah & 30 & $100 \%$ & \\
\hline
\end{tabular}


Dari tabel di atas ketuntasan peserta didik mencapai $80 \%$ yang terdiri dari $20 \%$ sangat kompoten, $20 \%$ kompoten dan $40 \%$ cukup kompoten. Sedangkan yang tidak tuntas mencapai 20\%. Hasil tersebut menunjukkan bahwa pada siklus II (kedua) secara klasikal peserta didik sudah tuntas. Data tabel di atas merupakan analisis peneliti dari jawaban-jawaban peserta didik pada waktu dilakukan uji kompetensi.

Uji kompetensi pada pembelajaran metode demonstrasi dan bermain peran memiliki fungsi untuk mengetahui secara tepat kompetensi peserta didik, memberi penguatan kepada peserta didik, meningkatkan hasil belajar peserta didik dan sebagainya

\section{Pembahasan Penelitian}

Berdasarkan temuan-temuan penelitian dari pernerapan model pembelajaran metode STAD dan hasil belajar siswa tersebut di atas, maka dapat dijelaskan. Beranjak dari hasil-hasil atau temuan dalam tindakan kelas yang sudah didiskripsikan di atas, peneliti menganalisis perkembangan hasil setiap siklus sehingga akan tergambar perkembangan hasil tindakan siklus I dan II, titik perbedaan dan persamaannya, serta terjadi peningkatan dari siklus ke siklus.

\section{Hasil Observasi Aktivitas Peserta Didik}

Pada siklus I (pertama), tingkat aktivitas belajar peserta didik di Kelas XI IPA1 SMA Negeri 1 Pontianak dalam pembelajaran Pendidikan Agama Islam: aspek akhlak materi sikap Jujur dengan menggunakan metode STAD belum mencapai katagori kriteria ketuntasan, karena rata-rata skor dari indikator sikap, keaktifan, respon, kemampuan, kerjasama dan kebenaran syariat peserta didik dalam mengikuti pembelajaran hanya mendapat persentase $74,7 \%$. Sedangkan indikator keberhasilan penelitian tindakan kelas ini adalah $80 \%$.

Pada siklus II (kedua) aktifitas belajar peserta didik mengalami peningkatan dari $74,7 \%$ menjadi $84,1 \%$. Jadi aktifitas peserta didik siklus II (kedua) dikatakan sudah mencapai ketuntasan secara individu maupun secara klasikal.

Demikian juga halnya dengan hasil temuan pada siklus III (ketiga), aktivitas belajar peserta didik terlihat baik/sangat tinggi. Hal ini disebabkan peserta didik sudah memahami teknik mengikuti pembelajaran dengan metode STAD. Untuk melihat terjadinya peningkatan aktifitas peserta didik dari siklus ke siklus dapat dilihat dari tabel berikut ini

Tabel 5. Perbandingan Aktivitas Peserta Didik Persiklus

\begin{tabular}{|l|l|l|l|}
\hline No & Indikator & Siklus I & Siklus II \\
\hline 1 & Sikap & $74 \%$ & $85,3 \%$ \\
\hline 2 & Keaktifan & $74 \%$ & $84,7 \%$ \\
\hline 3 & Respon & $76 \%$ & $81,3 \%$ \\
\hline 4 & Kemampuan & $73,3 \%$ & $81,3 \%$ \\
\hline 5 & Kerjasama & $75.3 \%$ & $84 \%$ \\
\hline 6 & Kebenaran syari`ah & $75,3 \%$ & $88 \%$ \\
\hline Rata-rata Persentase & \multicolumn{2}{|c|}{$74,7 \%$} & $84,1 \%$ \\
\hline
\end{tabular}

Pada tabel di atas terlihat secara keseluruhan indikator atau aspek yang diamati dari siklus ke siklus mengalami peningkatan persentase. Baik unsur sikap, keaktifan, respon, kemampuan, kerjasama dan kebenaran syariat peserta didik dalam pembelajaran metode STAD.

2. Pembelajaran Aktivitas Peserta Didik

Aspek aktivitas peserta didik terjadi peningkatan dari sebelumnya $74,7 \%$ menjadi $84,1 \%$ menjadi $92 \%$. Kondisi ini didukung dengan beberapa faktor yang dapat mempengaruhi hasil belajar peserta didik. Misalnya pada setiap tindakan peneliti melakukan tahap perencanaan pembelajaran yang matang mengikuti tahap-tahap pelaksanaan pembelajaran metode STAD. Selain itu peserta didik telah mengemukakan bahwa mereka cepat memahami 
pelajaran Pendidikan Agama Islam aspek akhlak materi berpakaian dan berhias serta bertamu dan menerima tamu melalui pembelajaran metode STAD.

Indikasi munculnya aktivitas belajar peserta didik ditandai dengan sebagian besar atau lebih dari $80 \%$ (indikator keberhasilan tindakan kelas) bersikap baik terhadap peserta didik lain 94,7\%, aktif mengikuti pembelajaran $89,3 \%$, memberi respon terhadap permasalahan 91,3\%, kemampuan dalam pembelajaran 90,7\%, bekerjasama dalam kelompok $90,7 \%$ dan kebenaran syariat dalam mendemonstrasikan serta memerankan materi $95,3 \%$.

\section{Hasil Belajar Peserta Didik}

Pada awalnya siklus I, hasil belajar peserta didik belum mencapai kompetensi yang diharapkan karena hasil ketuntasan peserta didik hanya mencapai $37,7 \%$. Selanjutnya pada siklus II (kedua), ketuntasan peserta didik meningkat mencapai $80 \%$. Berarti pada siklus II nilai sudah mencapai ketuntasan secara klasikal yaitu $80 \%$. Ini berarti pembelajaran jujur berhasil dengan menggunakan metode STAD.

Hal ini dikuatkan oleh pernyataan Fu'ad bin Abdul Aziz Asy-Syalhub, bahwa menyajikan dan menyuguhkan materi pelajaran melalui metode ceramah adalah media yang bagus di dalam memperoleh dan menuntut ilmu Akan tetapi metode ini akan bisa mencapai hasil gemilang bila bergabung dengan metode praktek/demonstrasi. Salah satu kelebihan metode demonstarasi adalah: "keaktifan dan pengalaman peserta didik akan bertambah, karena peserta didik ikut membantu pelaksanaan suatu demonstrasi sehingga ia menerima pengalaman yang bisa mengembangkan kecakapannya, dan pelajaran yang diberikan lebih tahan lama (Fu’ad bin Abdul Aziz asy-Syalhub, 2008: 103)

Metode STAD (Student Teams Achievement Division) ini adalah metode mengajar dengan cara memperagakan barang, kejadian, aturan, dan urutan melakukan suatu kegiatan, baik secara langsung maupun melalui penggunaan media pengajaran yang relevan dengan pokok bahasan yang sedang disajikan. Tujuan pokok menggunakan Metode STAD dalam proses pembelajaran adalah untuk memperjelas pengertian konsep dan memperlihatkan cara melakukan sesuatu atau proses terjadinya sesuatu (Shofwah, 2020).

Metode STAD (Student Teams Achievement Division) pada dasarnya melibatkan peserta didik untuk memerankan atau mendemonstrasikan tingkah laku manusia dalam hubungannya dengan masalah sosial. Metode ini dapat dipergunakan di dalam mempraktik isi pelajaran yang baru, mereka diberi kesempatan seluas-luasnya untuk memerankan sehingga menemukan kemungkinan masalah yang akan dihadapi dalam pelaksanaan sesungguhnya (Ibrahim, Muslimin (2000: 122)

Dari temuan-temuan di atas terbukti bahwa ketika pembelajaran bersifat teacher centered maka perolehan hasil belajar jauh dibawah batas kriteria ideal ketuntasan minimal. Tetapi setelah dilakukan pembelajaran yang bersifat teacher centered beralih menjadi student centered, peserta didik terpacu untuk beraktivitas karena metode STAD memberi peluang yang besar kepada mereka untuk bekerja sama, berpartisipasi, dan beraspirasi.

\section{KESIMPULAN}

Berdasarkan data yang diperoleh dari hasil observasi dan tes hasil belajar sebagaimana yang telah dipaparkan pada bab IV, maka untuk menjawab rumusan masalah dalam penelitian tindakan kelas ini dapat dikemukakan kesimpulan sebagai berikut: Aktivitas peserta didik selama mengikuti proses pembelajaran dengan menerapkan metode STAD menunjukkan peningkatan yang memuaskan. Hal ini terlihat dari hasil persentase peserta didik pada siklus I (pertama) 75,7\% dan pertemjuan siklus II (kedua) menjadi 84,1\%. Hasil belajar peserta didik Kelas XI IPA1 SMA Negeri 1 Pontianak tahun pelajaran 2018/2019 mengalami peningkatan untuk kategori sangat baik dari 38,7\% pada tes akhir pertemuan pertama menjadi $80 \%$ pada tes akhir pada pertemuan kedua dan menjadi $91 \%$. 


\section{DAFTAR PUSTAKA}

Al Rasyidin. (2008). Falsafah Pendidikan Islami. Bandung: Citapustaka Media Perintis Darsono, Max dkk . (2000). Belajar dan Pembelajaran. Semarang: CV IKIP Semarang Press. Fu`ad bin Abdul Aziz asy-Syalhub. (2008). Begini Seharusnya Menjadi Guru. Jakarta: Darul Haq.

Hidayat, Komaruddin. (2002). Aktive Learnig, 101 Strategi Pembelajaran Aktif. Yogyakarta: Yupondis.

Hidayat, Komaruddin. (2002). Aktive Learnig, 101 Strategi Pembelajaran Aktif. Yogyakarta: Yupondis

Ibrahim, Muslimin. (2000). Pembelajaran Kooperatif. Surabaya: University Press.

Iskandar. (2009). Penelitian Tindakan Kelas. Jambi: GP Press.

Nizar, Samsul. (2002). Filsafat Pendidikan Islam , pendekatan Historis, Teoritis dan Praktis, Jakarta: Ciputat Pers

Ratumanan, Tanwey Gerson. (2002). Belajar dan Pembelajaran. Surabaya: Unesa University. Shofwah. (2020). Dasar-Dasar Penelitian Pendidikan. Pontianak: STAIN Press 